\title{
Tumor Necrosis Factor- $\alpha$-mediated Decrease in Glutathione Increases the Sensitivity of Pulmonary Vascular Endothelial Cells to $\mathrm{H}_{2} \mathrm{O}_{2}$
}

\author{
Yoshiki Ishii, ${ }^{\star}$ Catherine A. Partridge, ${ }^{\star}$ Peter J. Del Vecchio, ${ }^{\star \star}$ and Asrar B. Malik ${ }^{\star}$ \\ Departments of *Physiology and Cell Biology and ${ }^{\ddagger}$ Ophthalmology, The Albany Medical College of Union University, \\ Albany, New York 12208
}

\begin{abstract}
We examined the effects of tumor necrosis factor- $\alpha$ (TNF $\alpha)$ stimulation of endothelial cells on the increase in endothelial permeability induced by $\mathrm{H}_{2} \mathrm{O}_{2}$. Bovine pulmonary microvascular endothelial cells (BPMVEC) were grown to confluence on a microporous filter and the ${ }^{125} \mathrm{I}$-albumin clearance rate across the monolayer was determined. Pretreatment with TNF $\alpha(100$ $\mathrm{U} / \mathrm{ml}$ ) for $6 \mathrm{~h}$ had no direct effect on transendothelial ${ }^{125} \mathrm{I}-\mathrm{albu}-$ min permeability. However, TNF $\alpha$ pretreatment enhanced the susceptibility of BPMVEC to $\mathrm{H}_{2} \mathrm{O}_{2}$; that is, $\mathrm{H}_{2} \mathrm{O}_{2}(10 \mu \mathrm{M})$ alone had no direct effect, whereas $\mathrm{H}_{2} \mathrm{O}_{2}$ increased ${ }^{125} \mathrm{I}$-albumin permeability more than threefold when added to monolayers pretreated for $6 \mathrm{~h}$ with TNF $\alpha$. Determination of lactate dehydrogenase release indicated that increased permeability was not due to cytolysis. We measured the intracellular contents of GSH and catalase to determine their possible role in mediating the increased susceptibility to $\mathrm{H}_{2} \mathrm{O}_{2}$. TNF $\alpha$ treatment $(100 \mathrm{U} /$ $\mathrm{ml}$ for $6 \mathrm{~h}$ ) decreased total GSH content and concomitantly increased the oxidized GSH content, but did not alter the cellular catalase activity. The role of GSH was examined by pretreating endothelial cells with $2 \mathrm{mM}$ GSH for $3 \mathrm{~h}$, which produced an $80 \%$ increase in intracellular GSH content. GSH repletion inhibited the increased sensitivity of the TNF $\alpha$-treated endothelial cells to $\mathrm{H}_{2} \mathrm{O}_{2}$. We tested the effects of xanthine oxidase (XO) inhibition since $\mathrm{XO}$ activation may be a source of oxidants responsible for the decrease in cellular GSH content. Pretreatment with $0.5 \mathrm{mM}$ oxypurinol attenuated the synergistic effect of TNF $\alpha$ and $\mathrm{H}_{2} \mathrm{O}_{2}$ on endothelial permeability. The results indicate that decreased oxidant buffering capacity secondary to TNF $\alpha$-induced reduction in intracellular GSH content mediates the increased susceptibility of endothelial cells to $\mathrm{H}_{2} \mathrm{O}_{2}$. This mechanism may contribute to oxidant-dependent vascular endothelial injury in septicemia associated with TNF $\alpha$ release. (J. Clin. Invest. 1992. 89:794-802.) Key words: endothelial permeability $\bullet$ oxygen free radicals $\bullet$ anti-oxidants $\bullet$ cytokines • vascular injury
\end{abstract}

Dr. Ishii's permanent address is Department of Pulmonary Medicine, Jichi Medical School, Tochigi, Japan 329-04.

Address correspondence to Dr. A. B. Malik, The Albany Medical College, 47 New Scotland Ave., Albany, NY 12208.

Received for publication 10 April 1991 and in revised form 7 October 1991.

J. Clin. Invest.

(C) The American Society for Clinical Investigation, Inc.

0021-9738/92/03/0794/09 \$2.00

Volume 89, March 1992, 794-802

\section{Introduction}

Tumor necrosis factor- $\alpha(\mathrm{TNF} \alpha)^{1}$ is an important mediator of endotoxic shock and the associated high permeability pulmonary edema $(1,2)$. Infusion of human recombinant TNF $\alpha$ has been shown to induce a vascular "leak" syndrome in animal models $(3,4)$. There are two described pathways involved in TNF $\alpha$-induced vascular endothelial injury: (a) direct effects of TNF $\alpha$ and of secondary mediators released by TNF $\alpha$ on endothelial cells, and (b) a neutrophil (PMN)-dependent pathway. In support of the first pathway, reports indicate that TNF $\alpha$ can directly increase endothelial permeability in vitro $(3,5-7)$ and in vivo (3). The TNF $\alpha$-induced release of inflammatory mediators such as platelet activating factor (8), interleukin 1 (9), granulocyte-macrophage colony-stimulating factor (10), and possibly reactive oxygen species $(11,12)$ may contribute to the permeability-increasing effect of TNF $\alpha$. The second pathway involving PMN (13-16) may be the result of TNF $\alpha$-induced augmentation of PMN activation, resulting in the release of oxygen free radicals (17) and arachidonic acid metabolites (18). The released oxidants, in particular $\mathrm{H}_{2} \mathrm{O}_{2}$, can directly increase vascular endothelial permeability (19). TNF $\alpha$ can also mediate PMN adhesion to endothelial cells by increasing the expression of adhesion molecules $(20,21)$ and thereby promote cell-cell contact and enhance PMN activation (22).

Recent studies have suggested a third potentially important mechanism involving TNF $\alpha$-mediated increase in the susceptibility of vascular endothelial cells to oxidants $(23,24)$. The possibility has been raised that TNF $\alpha$ can interfere with the intracellular oxidant buffering capacity such that cells become more sensitive to oxidant-mediated injury $(25,26)$. Moreover, we have recently shown that $\mathrm{TNF}_{\alpha}$ augmented $\mathrm{PMN}$-mediated endothelial injury (26a), which could be ascribed to an effect of $\mathrm{TNF}_{\alpha}$ on endothelial anti-oxidants. In this study we examined whether such a mechanism contributed to the increase in endothelial permeability in response to oxidant exposure. We measured the alterations in permeability of TNF $\alpha$-treated bovine pulmonary microvascular endothelial cells in response to $\mathrm{H}_{2} \mathrm{O}_{2}$ and the roles of GSH and catalase, the primary intracellular antioxidant defenses against $\mathrm{H}_{2} \mathrm{O}_{2}$.

\section{Methods}

Reagents. DME, HBSS, and fetal bovine serum (FBS) were purchased from Gibco Laboratories, Grand Island, NY. BSA (Fraction V), Hepes, 5,5'-dithiobis(2-nitrobenzoic acid) (DTNB), NADPH, glutathione reductase, 4-vinylpyridine, hydrogen peroxide ( $30 \%$ solution), GSH, and

1. Abbreviations used in this paper: BPMVEC, bovine pulmonary microvascular endothelial cells; DTNB, 5,5'-dithiobis(2-nitrobenzoic acid); FBS, fetal bovine serum; GSSG, oxidized glutathione; LDH, lactate dehydrogenase; TNF $\alpha$, tumor necrosis factor- $\alpha$; XO, xanthine oxidase. 
oxypurinol were purchased from Sigma Chemical Co., St. Louis, MO. ${ }^{125}$ I was obtained from New England Nuclear, Boston, MA.

Pulmonary microvascular endothelial cells. Bovine pulmonary microvascular endothelial cells (BPMVEC) were isolated using the technique described previously (27). Briefly, tissue from the periphery of bovine lung was minced, exposed to collagenase, filtered, centrifuged, and resuspended in DME containing 20\% FBS. After several days of incubation, colonies were selected based on uniform morphology and isolated with a cloning ring. The cells were confirmed to be endothelial in origin by the presence of Factor VIII-related antigen and incorporation of acylated LDL. The endothelial cells were harvested at 18-24 population doublings using $0.025 \%$ trypsin and centrifuged at $100 \mathrm{~g}$ for $5 \mathrm{~min}$. The cells were resuspended in culture media at $2 \times 10^{5}$ cells $/ \mathrm{ml}$ and seeded as described below.

Preparation of monolayers on filters and permeability assay. Polycarbonate microporous membrane filters ( $13 \mathrm{~mm}$ diam, $0.8-\mu \mathrm{m}$ pore size; Nucleopore Corp., Pleasanton, CA) were coated with gelatin (type III calf skin gelatin; Sigma Chemical Co.) as previously described (28) and mounted on the bottom of plastic cylinders $(9 \mathrm{~mm}$ i.d.; Adaps, Dedham, MA). These cylinders were suspended in 12-well culture plates, sterilized by ultraviolet light for $24 \mathrm{~h}$, and coated with $30 \mu \mathrm{g} / \mathrm{ml}$ of ovine fibronectin. Endothelial cells were seeded with $0.5 \mathrm{ml}$ of cell suspension at a density of $2.0 \times 10^{5}$ cells $/ \mathrm{ml}$ and cultured for $4 \mathrm{~d}$ in $5 \%$ $\mathrm{CO}_{2}$ at $37^{\circ} \mathrm{C}$ to allow the cells to grow to confluency.

The system for determining transendothelial ${ }^{125} \mathrm{I}$-albumin flux has been described by us (29). Culture medium in the upper chamber (monolayer mounted cylinder) was replaced with $600 \mu$ l of HBSS containing $0.5 \% \mathrm{BSA}$ and $20 \mathrm{mM}$ Hepes (medium A) containing tracer ${ }^{125}$ I-labeled albumin. The upper chamber was floated by means of a styrofoam collar in a larger lower chamber filled with $25 \mathrm{ml}$ of medium A. The lower chamber was stirred continuously for complete mixing and the whole system was kept in a water bath at a constant temperature of $37^{\circ} \mathrm{C}$. After the addition of different concentration of $\mathrm{H}_{2} \mathrm{O}_{2}$ solution in $50 \mu \mathrm{l}$ of medium $\mathrm{A}$ to the upper compartment, samples were taken from the lower chamber every $5 \mathrm{~min}$ for $60 \mathrm{~min}$. The radioactivity of the samples was measured in a gamma counter and transendothelial clearance rates of ${ }^{125} \mathrm{I}$-albumin were calculated by weighted least-squares nonlinear regression (BMDP Statistical Software, Berkeley, CA) (29). The clearance rates were corrected for differences in free-to-bound ${ }^{125}$ I ratios by determination of free ${ }^{125}$ I concentrations using trichloroacetic acid precipitation.

Treatment of endothelial monolayers with TNF $\alpha$. Recombinant human TNF $\alpha$ (Cetus Corp., Emeryville, CA) with a specific bioactivity of $25 \times 10^{6} \mathrm{U} / \mathrm{mg}$ protein was used. Endotoxin contamination was 0.05 $\mathrm{ng} / \mathrm{ml}$ by a limulus amebocyte lysate assay. This level had no effect on the cellular parameters measured in this study. Confluent monolayers in DME containing $20 \%$ FBS were treated with TNF $\alpha$ in $50 \mu \mathrm{l} \mathrm{DME}$ to give a final concentration of $0,10^{2}, 10^{3}$, or $10^{4} \mathrm{U} / \mathrm{ml}$, and then incubated at $37^{\circ} \mathrm{C}$ for periods of 1,3 , or $6 \mathrm{~h}$.

In some studies heat-inactivated $\left(90^{\circ} \mathrm{C}, 20 \mathrm{~min}\right) \mathrm{TNF} \alpha$ was used to exclude the possible effects of contaminating endotoxin on endothelial permeability. Furthermore, neutralizing polyclonal rabbit anti-human TNF $\alpha$ antibody (gift of Dr. Mary E. Gerritsen, Miles Laboratories, New Haven, CT) or an equivalent concentration of nonrelevant control rabbit IgG (Calbiochem Corp., La Jolla, CA) was used to confirm that the observed effects were due to TNF $\alpha$.

In some experiments, $2 \mathrm{mM}$ reduced GSH was added to endothelial cells as described (30) at 0,3 , or $6 \mathrm{~h}$ before the permeability assay in order to increase the intracellular GSH concentration. In other experiments, the xanthine oxidase $(\mathrm{XO})$ inhibitor, oxypurinol $(0.5 \mathrm{mM})$, was added to monolayers 30 min before the application of TNF $\alpha$. Oxypurinol at $0.5 \mathrm{mM}$ inhibited the XO activity in BPMVEC (control XO activity was $1.40 \pm 0.16 \mathrm{nmol} / \mathrm{min}$ per $2 \times 10^{6}$ cells and the 6 -h postoxypurinol value was undetectable) as measured using the assay of Terada et al. (31).

Glutathione and catalase assays. We measured intracellular contents of GSH and catalase in BPMVEC after treatment with TNF $\alpha$ to determine possible alterations in these antioxidants. Endothelial cells were seeded onto six-well plastic tissue culture plates coated with fibronectin. Confluent monolayers were incubated for 1,3 , or $6 \mathrm{~h}$ with different concentrations of TNF $\alpha$ diluted into the culture medium. After incubation, monolayers were washed twice with PBS and lysed with $1 \%$ Triton $\mathrm{X}-100$.

To assay total GSH (i.e., the sum of reduced GSH and oxidized GSH [GSSG]), $100 \mu \mathrm{l}$ cell lysate was incubated at $30^{\circ} \mathrm{C}$ with $800 \mu \mathrm{l}$ of $0.3 \mathrm{mM}$ NADPH, $125 \mathrm{mM}$ sodium phosphate buffer with $6.3 \mathrm{mM}$ EDTA, pH 7.5, and $100 \mu \mathrm{l}$ of $6 \mathrm{mM}$ DTNB (32). After addition of $20 \mu \mathrm{l}$ of $25 \mathrm{U} / \mathrm{ml} \mathrm{GSH}$ reductase, the change in optical density at $412 \mathrm{~nm}$ was measured. To measure GSSG, GSH in samples was derivatized by adding $2 \mu \mathrm{l}$ of $20 \mathrm{mM}$ 4-vinylpyridine per $125 \mu \mathrm{l}$ solution and mixing vigorously for $1 \mathrm{~min}$. GSSG was measured in the same manner as GSH (32). The concentration of GSH was calculated as the difference between total GSH and GSSG. In parallel experiments, the number of endothelial cells was determined in order to express the results as the amount of GSH (nanomoles) per $10^{6}$ cells. In some experiments, the GSH and GSSH assays were carried out after exposure of endothelial cells to $2 \mathrm{mM} \mathrm{GSH}$ in culture medium for $1,2,3$, or $6 \mathrm{~h}$.

Catalase activity was determined using the assay described by Beers and Sizer (33). In a spectrophotometer cuvette, $1.9 \mathrm{ml}$ reagent grade water and $1 \mathrm{ml}$ of substrate solution consisting of $59 \mathrm{mM} \mathrm{H}_{2} \mathrm{O}_{2}$ in 0.05 $\mathrm{M}$ potassium phosphate ( $\mathrm{pH} 7.0$ ) were added. The cuvette was incubated in spectrophotometer for $5 \mathrm{~min}$, and $0.1 \mathrm{ml}$ of the cell lysate was added. The decrease in absorbance at $240 \mathrm{~nm}$ was recorded for 2-3 min

Lactate dehydrogenase. Lactate dehydrogenase (LDH) release from BPMVEC was determined to assess whether the permeability-increasing effects of TNF $\alpha$ were due to cytolysis. Endothelial monolayers were plated on six-well culture plates as above. The culture medium was removed after incubation with TNF $\alpha$ in DME containing 20\% FBS for $6 \mathrm{~h}$. Some monolayers were washed twice with PBS and reincubated for $1 \mathrm{~h}$ in $\mathrm{HBSS}$ with or without $10 \mu \mathrm{M} \mathrm{H}_{2} \mathrm{O}_{2}$. LDH activity was assayed in the culture media after $6 \mathrm{~h}$ incubation and after further $1 \mathrm{~h}$ incubation using an LDH assay kit (LD-L20; Sigma Diagnostics, St. Louis, MO). Released LDH was expressed as a percentage of total cellular LDH, which was determined after cell lysis with $1 \%$ Triton X-100. Values of LDH released into medium were corrected by subtracting the baseline LDH activity.

Morphologic analysis. Changes in the actin microfilament cytoskeleton of endothelial monolayers grown on filters were assessed using the rhodamine phalloidin stain (Molecular Probes, Inc., Eugene, OR) as described (34). Monolayers were examined and photographed using a fluorescence microscope equipped with epi-illumination (Nikon Optiphot; Nikon, Garden City, NY).

Statistics. Differences between two group means were compared by $t$ test. Multigroup comparisons were made by one-way analysis of variance.

\section{Results}

Effects of TNF $\alpha$ on endothelial permeability. Treatment of BPMVEC monolayers with TNF $\alpha\left(10^{2}-10^{4} \mathrm{U} / \mathrm{ml}\right)$ for $6 \mathrm{~h}$ increased the ${ }^{125} \mathrm{I}$-albumin transendothelial clearance rates (the measure of transendothelial albumin permeability) in a concentration-dependent manner (Fig. 1). The lowest concentration of TNF $\alpha\left(10^{2} \mathrm{U} / \mathrm{ml}\right)$, which we subsequently used for all studies reported below, had no independent effect on permeability. Monolayers exposed to $10^{3}$ or $10^{4} \mathrm{U} / \mathrm{ml}$ of TNF $\alpha$, however, showed significant increases in permeability within $1 \mathrm{~h}$ of challenge and in a time-dependent manner until $6 \mathrm{~h}$ (data not shown).

Addition of $\mathrm{H}_{2} \mathrm{O}_{2}(30-1,000 \mu \mathrm{M})$ to endothelial monolayers resulted in concentration-dependent increases in ${ }^{125} \mathrm{I}$-albumin permeability (Fig. 2). However, pretreatment with 100 $\mathrm{U} / \mathrm{ml}$ of TNF $\alpha$ for $6 \mathrm{~h}$ (which had no direct effect on permeabil- 


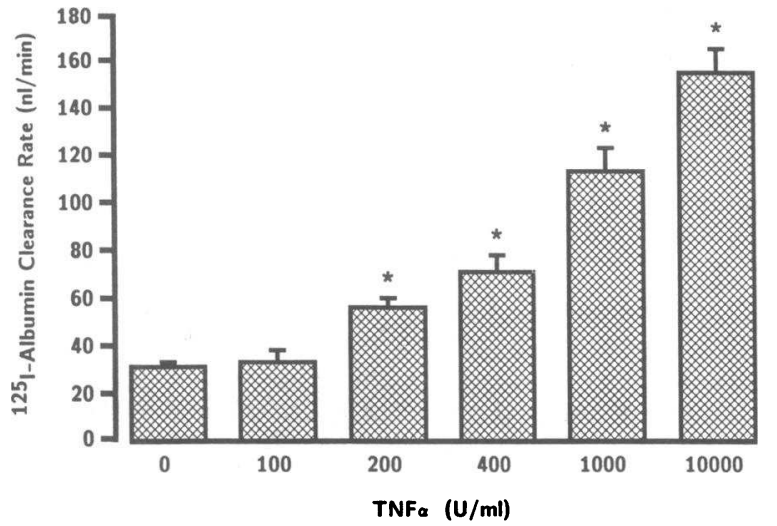

Figure 1. Effect of TNF $\alpha$ on transendothelial ${ }^{125} \mathrm{I}$-albumin clearance rate across the bovine pulmonary microvascular endothelial monolayers. Albumin clearance rates were measured for $1 \mathrm{~h}$ after a 6-h incubation with various concentrations of TNF $\alpha$. Values are means \pm SE; $n=8$ in each group. ${ }^{*} P<0.05$ compared with control.

ity itself, as shown in Fig. 1) significantly augmented the sensitivity of BPMVEC monolayers to $\mathrm{H}_{2} \mathrm{O}_{2} .10 \mu \mathrm{M} \mathrm{H}_{2} \mathrm{O}_{2}$, a concentration with no direct permeability-increasing effect, increased ${ }^{125} \mathrm{I}$-albumin transendothelial clearance rate more than threefold (Fig. 2). The increased sensitivity to $\mathrm{H}_{2} \mathrm{O}_{2}$ was not observed in monolayers treated with buffer (Fig. 2). The permeability-enhancing effect of TNF $\alpha$ pretreatment was not evident after $1 \mathrm{~h}$ treatment with $100 \mathrm{U} / \mathrm{ml} \mathrm{TNF} \alpha$; the effect became apparent only after $3 \mathrm{~h}$ and was augmented further after a 6-h TNF $\alpha$ treatment period (Fig. 3). Heat-inactivated TNF $\alpha$ had no permeability-enhancing effect (Fig. 4). Anti-TNF $\alpha$ antibody abolished the permeability-enhancing effect of TNF $\alpha$, but this did not occur with a control IgG (Fig. 4).

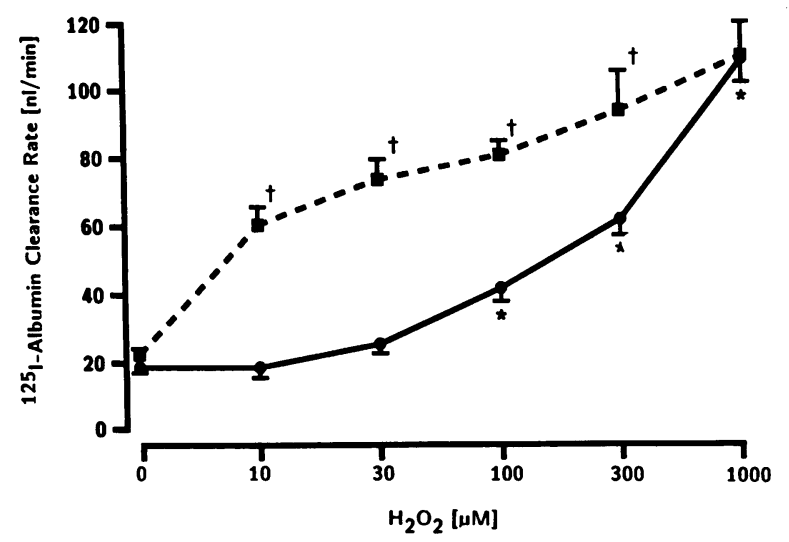

Figure 2. Effect of TNF $\alpha$ on endothelial susceptibility to $\mathrm{H}_{2} \mathrm{O}_{2}$-induced increase in permeability. Bovine pulmonary microvascular endothelial monolayers were preincubated with ( $₫$ ) or without $(\bullet) 100$ $\mathrm{U} / \mathrm{ml} \mathrm{TNF} \alpha$ for $6 \mathrm{~h}$ and the transendothelial ${ }^{125} \mathrm{I}$-albumin clearance rates were measured for $1 \mathrm{~h}$ after addition of varying concentrations of $\mathrm{H}_{2} \mathrm{O}_{2} \cdot \mathrm{H}_{2} \mathrm{O}_{2}$ increased ${ }^{125} \mathrm{I}$-albumin permeability in control monolayers without TNF $\alpha$ pretreatment in a dose-dependent manner (solid line). Pretreatment with TNF $\alpha$ significantly enhanced the response to $\mathrm{H}_{2} \mathrm{O}_{2}$ (dashed line). Values are means $\pm \mathrm{SE} ; n=8$ in each group. ${ }^{*} P<0.05$ compared with $0 \mu \mathrm{M}$ of $\mathrm{H}_{2} \mathrm{O}_{2} .{ }^{\dagger} P<0.05$ compared with control monolayers without TNF $\alpha$.

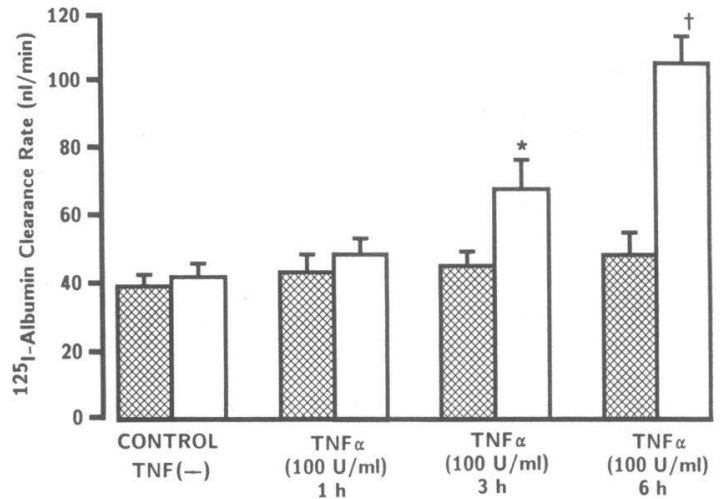

Figure 3. Time course of the "priming" effect of TNF $\alpha$ on endothelial sensitivity to $\mathrm{H}_{2} \mathrm{O}_{2}$-induced increase in permeability. Bovine pulmonary microvascular endothelial monolayers were preincubated with (open bars) or without (cross-hatched bars) $100 \mathrm{U} / \mathrm{ml}$ of TNF $\alpha$ for 1,3 , or $6 \mathrm{~h}$. The transendothelial ${ }^{125} \mathrm{I}$-albumin clearance rates were measured after addition or no addition of $10 \mu \mathrm{M} \mathrm{H}_{2} \mathrm{O}_{2}$. Values are mean \pm SE; $n=8$ in each group. ${ }^{*} P<0.05$ and ${ }^{\dagger} P<0.01$ compared with monolayers without $\mathrm{H}_{2} \mathrm{O}_{2}$.

Cytotoxicity assay of $\mathrm{TNF} \alpha$ and $\mathrm{H}_{2} \mathrm{O}_{2}$. Treatment of BPMVEC with TNF $\alpha\left(10^{2}, 10^{3}, 10^{4} \mathrm{U} / \mathrm{ml}\right)$ for $6 \mathrm{~h}$ and treatment with $10 \mu \mathrm{M} \mathrm{H}_{2} \mathrm{O}_{2}$ for $1 \mathrm{~h}$ after the $100 \mathrm{U} / \mathrm{ml} \mathrm{TNF} \alpha$ for $6 \mathrm{~h}$ did not increase $\mathrm{LDH}$ release (Table I). This finding indicates that the increase in endothelial permeability was not due to a cytolytic effect of TNF $\alpha$ when combined with $\mathrm{H}_{2} \mathrm{O}_{2}$. Monolayer cell numbers were also not altered by these interventions.

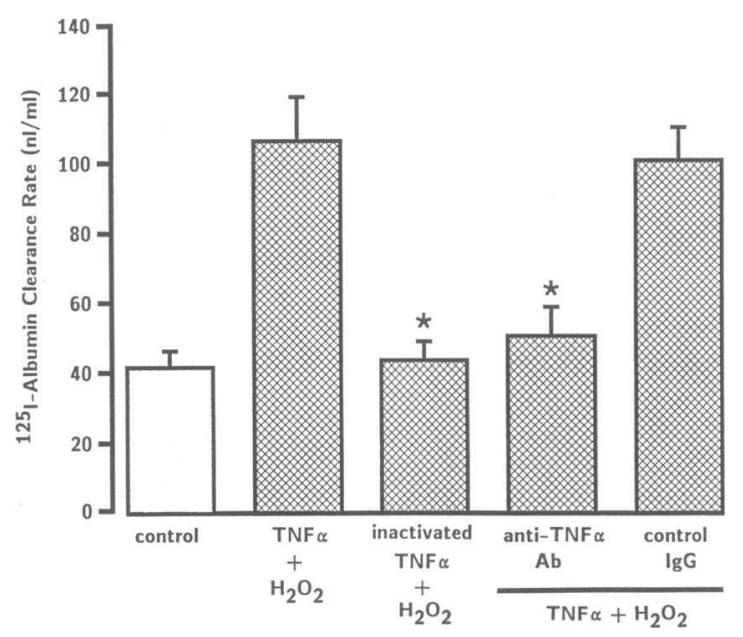

Figure 4. Effect of anti-TNF $\alpha$ antibody and heat-inactivated TNF $\alpha$ on the permeability-enhancing effect. Polyclonal anti-TNF $\alpha$ antibody was preincubated with TNF $\alpha$ for $30 \mathrm{~min}$ and then applied to endothelial monolayers. An equivalent concentration of nonrelevant rabbit IgG was used as a control protein. Heat-inactivated TNF $\alpha\left(100^{\circ} \mathrm{C}\right.$, $20 \mathrm{~min}$ ) was also used instead of TNF $\alpha$. Endothelial monolayers were incubated for $6 \mathrm{~h}$ with TNF $\alpha(100 \mathrm{U} / \mathrm{ml})$, a combination of TNF $\alpha$ and anti-TNF $\alpha$ antibody, or heat-inactivated TNF $\alpha$. The medium was then replaced with buffer. The transendothelial ${ }^{125} \mathrm{I}$-albumin clearance rates were measured after addition of $10 \mu \mathrm{M} \mathrm{H}_{2} \mathrm{O}_{2}$. Values are means $\pm \mathrm{SE} ; n=8$ in each group. ${ }^{*} P<0.01$ decreased when compared with the TNF $\alpha+\mathrm{H}_{2} \mathrm{O}_{2}$ group. 
Table I. LDH Release from Pulmonary Microvascular Endothelial Cells

\begin{tabular}{cc}
\hline \multicolumn{1}{c}{ Treatment } & \% LDH \\
\hline $\mathrm{TNF} \alpha(\mathrm{U} / \mathrm{ml})$ for $6 \mathrm{~h}^{\ddagger}$ & \\
0 & $6.8 \pm 1.1$ \\
100 & $6.5 \pm 0.7$ \\
1,000 & $5.9 \pm 0.8$ \\
10,000 & $6.5 \pm 1.6$ \\
$\mathrm{H}_{2} \mathrm{O}_{2}$ treatment for $1 \mathrm{~h}^{\S}$ & \\
Control cells $+\mathrm{H}_{2} \mathrm{O}_{2}, 0 \mu \mathrm{M}$ & $1.0 \pm 0.5$ \\
Control cells $+\mathrm{H}_{2} \mathrm{O}_{2}, 10 \mu \mathrm{M}$ & $0.8 \pm 0.3$ \\
TNF $\alpha$ pretreated cells $+\mathrm{H}_{2} \mathrm{O}_{2}, 0 \mu \mathrm{M}$ & $0.7 \pm 0.4$ \\
TNF $\alpha$ pretreated cells $+\mathrm{H}_{2} \mathrm{O}_{2}, 10 \mu \mathrm{M}$ & $1.2 \pm 0.4$ \\
\end{tabular}

Values are means $\pm \mathrm{SE} ; n=4$.

* \%LDH $=(\mathrm{LDH}$ in medium/[LDH in medium $+\mathrm{LDH}$ in cell lysate] $) \times 100$.

₹ BPMVEC were incubated with various concentrations of TNF $\alpha$ in DME with $20 \%$ FBS. Values were corrected by subtraction of baseline LDH activity in the culture medium.

${ }^{8}$ BPMVEC were washed with PBS after incubation with or without TNF $\alpha(100 \mathrm{U} / \mathrm{ml})$ for $6 \mathrm{~h}$, and then further incubated with or without $\mathrm{H}_{2} \mathrm{O}_{2}(10 \mu \mathrm{M})$ in HBSS for $1 \mathrm{~h}$.

Changes in GSH and catalase. Treatment with $\mathrm{TNF} \alpha\left(10^{2}-\right.$ $10^{4} \mathrm{U} / \mathrm{ml}$ ) for $6 \mathrm{~h}$ significantly decreased intracellular GSH content in a concentration-dependent manner (Table II). The decrease in GSH was associated with an increase in GSSG such that the GSSG/GSH ratio increased significantly after TNF $\alpha$ treatment. The effect of TNF $\alpha$ was time dependent; that is, treatment with $100 \mathrm{U} / \mathrm{ml} \mathrm{TNF} \alpha$ for $1 \mathrm{~h}$ showed no change in either GSH or GSSH content, $3 \mathrm{~h}$ TNF $\alpha$ treatment showed a small decrease $(P<0.05)$ in GSH, which became more pronounced after $6 \mathrm{~h} \mathrm{TNF} \alpha$ treatment and was accompanied by an increase in GSSH (Table II). GSSG concentration in the culture medium was also increased from $0.12 \pm 0.02$ (control) to $0.17 \pm 0.02 \mathrm{nmol} / \mathrm{ml}$ after TNF $\alpha$ treatment $(100 \mathrm{U} / \mathrm{ml}, 6 \mathrm{~h})$ $($ mean \pm SE; $P<0.05$ ). In contrast, the BPMVEC catalase activity was not significantly altered at any time point within $6 \mathrm{~h}$ after TNF $\alpha$ treatment (Table III).

Table II. Changes in Intracellular Glutathione Content after Exposure to TNF $\alpha$

\begin{tabular}{|c|c|c|c|c|}
\hline $\mathrm{TNF} \alpha$ & & GSH & GSSG & GSSG/GSH ratio \\
\hline$U / m l$ & & \multicolumn{2}{|c|}{ nmol/10 cells } & \\
\hline Control & & $6.20 \pm 0.16$ & $0.25 \pm 0.03$ & $0.040 \pm 0.004$ \\
\hline 100 & $1 \mathrm{~h}$ & $6.22 \pm 0.20$ & $0.26 \pm 0.03$ & $0.041 \pm 0.005$ \\
\hline 100 & $3 \mathrm{~h}$ & $5.58 \pm 0.16^{*}$ & $0.27 \pm 0.02$ & $0.050 \pm 0.005^{*}$ \\
\hline 100 & $6 \mathrm{~h}$ & $5.25 \pm 0.26^{*}$ & $0.30 \pm 0.03^{*}$ & $0.059 \pm 0.007^{*}$ \\
\hline 1,000 & $6 \mathrm{~h}$ & $4.71 \pm 0.38^{*}$ & $0.34 \pm 0.02^{*}$ & $0.078 \pm 0.009^{*}$ \\
\hline 10,000 & $6 \mathrm{~h}$ & $4.28 \pm 0.25^{*}$ & $0.36 \pm 0.03^{*}$ & $0.086 \pm 0.008^{*}$ \\
\hline
\end{tabular}

Values are means $\pm \mathrm{SE} ; n=8-12$ per group. BPMVEC were incubated with various concentrations of TNF $\alpha$ in culture medium.

* Increased or decreased from control; $P<0.05$.
Table III. Catalase Activity in BPMVEC after 6-h Treatment with $T N F \alpha$

\begin{tabular}{ccccc}
\hline $\mathrm{TNF} \alpha$ & 0 & 100 & 1,000 & 10,000 \\
\hline$U / m l$ & & & & \\
$\begin{array}{c}\text { Catalase } \\
\left(\mathrm{U} / 10^{6} \text { cells }\right)\end{array}$ & $6.09 \pm 0.15$ & $6.37 \pm 0.20$ & $6.08 \pm 0.18$ & $5.85 \pm 0.12$
\end{tabular}

Values are means $\pm \mathrm{SE} ; n=6$.

Effect of exogenous GSH on intracellular GSH and GSSG. Intracellular total GSH content increased in a time-dependent manner after addition of $2 \mathrm{mM}$ reduced GSH to the culture medium, and the GSH value reached a plateau at twice the control value by $3 \mathrm{~h}$ (Fig. 5). The increase in intracellular GSH content was not influenced by the presence of $100 \mathrm{U} / \mathrm{ml} \mathrm{TNF} \alpha$ in the culture medium (Fig. 5). Changes in GSH and GSSG contents and GSSG/GSH ratios are shown in Table IV. The increase in cellular GSH content was accompanied by an increase in the GSSG content after treatment with exogenous GSH (Table IV).

Effect of exogenous GSH on endothelial permeability. We examined the effects of GSH supplementation on the $\mathrm{H}_{2} \mathrm{O}_{2}$-induced increase in permeability of TNF $\alpha$-pretreated endothelial monolayers. GSH was added to BPMVEC culture media at the beginning, at the halfway point (i.e., at $3 \mathrm{~h}$ ), or at the end of $6 \mathrm{~h}$ $\mathrm{TNF} \alpha$ treatment, and was coincubated for 6,3 , or $0 \mathrm{~h}$, respectively. The 3-h treatment with GSH (which doubled the intracellular GSH content [as shown in Fig. 5]) significantly reduced the rise in ${ }^{125}$ I-albumin permeability mediated by the combination of TNF $\alpha$ and $\mathrm{H}_{2} \mathrm{O}_{2}$ regimen (Fig. 6). A 6-h period of GSH incubation was as protective as the 3-h GSH incubation period (Fig. 6), which is consistent with 3- and 6-h GSH treatment periods producing the same increases in intracellular GSH content (Fig. 5). Treatment with GSH alone for $6 \mathrm{~h}$ had no effect on baseline permeability. In the control group $(0 \mathrm{~h})$, GSH was added and immediately removed when the $6 \mathrm{~h} \mathrm{TNF} \alpha$ treatment period ended, and the cells were then challenged with

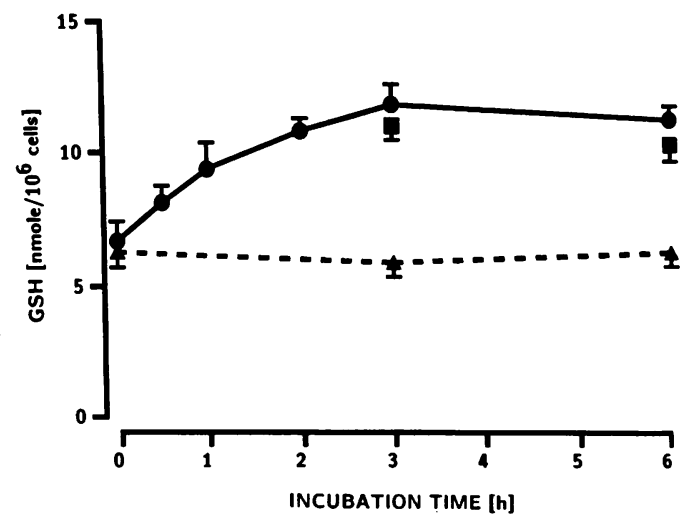

Figure 5. Effect of exogenous GSH on intracellular total GSH content in pulmonary microvascular endothelial cells. Monolayers were incubated with $2 \mathrm{mM}$ GSH in the presence (squares) or absence (circles) of TNF $\alpha(100 \mathrm{U} / \mathrm{ml})$ for $0,1,2,3$, or $6 \mathrm{~h}$. Baseline values of GSH in untreated cells showed no change (triangles). Values are mean $\pm \mathrm{SE}$; $n=4-6$ in each group. 
Table IV. Changes in GSH and GSSG Content after Treatment with Exogenous GSH and TNF $\alpha$

\begin{tabular}{|c|c|c|c|}
\hline & GSH & GSSG & $\begin{array}{c}\text { GSSG/GSH } \\
\text { ratio }\end{array}$ \\
\hline \multicolumn{4}{|c|}{ nmol $/ 10^{6}$ cells } \\
\hline Control & $6.09 \pm 0.25$ & $0.15 \pm 0.06$ & $0.024 \pm 0.004$ \\
\hline GSH $3 \mathrm{~h}$ & $10.7 \pm 0.75^{*}$ & $0.38 \pm 0.08^{*}$ & $0.034 \pm 0.008$ \\
\hline GSH $6 \mathrm{~h}$ & $10.3 \pm 0.58^{*}$ & $0.33 \pm 0.10^{*}$ & $0.032 \pm 0.012$ \\
\hline $\mathrm{TNF} \alpha 6 \mathrm{~h}$ & $5.43 \pm 0.20^{\ddagger}$ & $0.28 \pm 0.08^{*}$ & $0.049 \pm 0.010^{*}$ \\
\hline \multicolumn{4}{|l|}{ TNF $\alpha 6 h^{8}$} \\
\hline$+\mathrm{GSH} 3 \mathrm{~h}$ & $10.0 \pm 0.94^{*}$ & $0.35 \pm 0.11^{*}$ & $0.035 \pm 0.011$ \\
\hline \multicolumn{4}{|l|}{$\mathrm{TNF} \alpha 6 \mathrm{~h}^{8}$} \\
\hline+ GSH 6 h & $10.8 \pm 1.15^{*}$ & $0.40 \pm 0.16^{*}$ & $0.037 \pm 0.013$ \\
\hline
\end{tabular}

Values are mean \pm SE; $n=6$ per group. Exogenous GSH concentration was $2 \mathrm{mM}$. TNF $\alpha$ concentration was $100 \mathrm{U} / \mathrm{ml}$.

* Increased from control; $P<0.05$.

${ }^{\ddagger}$ Decreased from control; $P<0.05$.

${ }^{8}$ Endothelial cells were treated with TNF $\alpha$ and GSH at the same time.

$\mathrm{H}_{2} \mathrm{O}_{2}$. This short-term GSH incubation period had no protective effect (Fig. 6), excluding the possibility that residual extracellular contamination with GSH was responsible for the protective effect of GSH repletion.

Effect of oxypurinol on intracellular GSH and GSSG. Oxypurinol treatment $(0.5 \mathrm{mM} ; 6 \mathrm{~h})$ slightly increased intracellular GSH and GSSG as compared with the control value (Table V). The GSSG/GSH ratio also increased. Addition of oxypurinol 30 min before TNF $\alpha$ treatment prevented the decrease in GSH content induced by the 6-h TNF $\alpha$ treatment period (Table V).

Effect of oxypurinol on permeability. Treatment of BPMVEC with $0.5 \mathrm{mM}$ oxypurinol $30 \mathrm{~min}$ before addition of

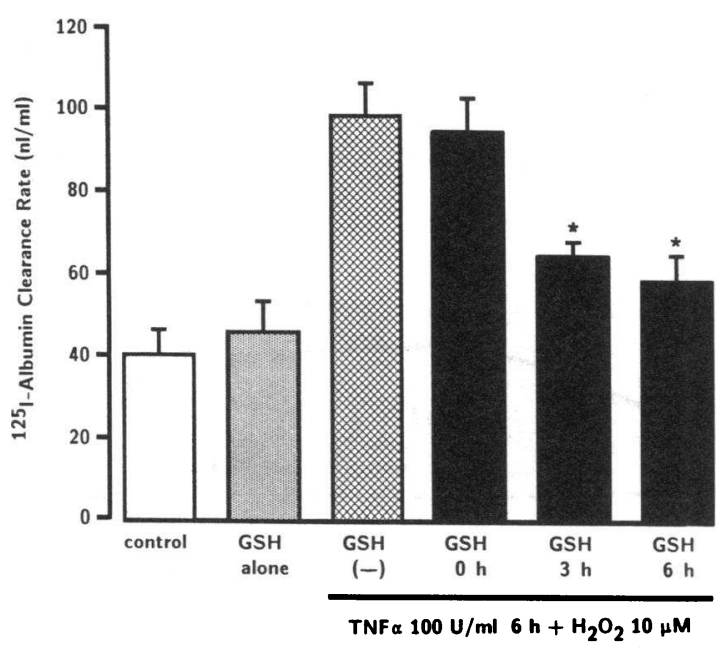

Figure 6. Effect of exogenous GSH on increased endothelial permeability induced by a combination of TNF $\alpha(100 \mathrm{U} / \mathrm{ml}$ for $6 \mathrm{~h})$ and subsequent $\mathrm{H}_{2} \mathrm{O}_{2}(10 \mu \mathrm{M}) .2 \mathrm{mM}$ GSH was added to the medium at the beginning, halfway point, or end of 6-h TNF $\alpha$ treatment and coincubated for 6,3 , or $0 \mathrm{~h}$, respectively. The medium was then replaced with buffer. The transendothelial ${ }^{125} \mathrm{I}$-albumin clearance rates were measured after addition of $\mathrm{H}_{2} \mathrm{O}_{2}$. Values are means $\pm \mathrm{SE} ; n=8$ in each group. ${ }^{*} P<0.05$ decreased when compared with TNF $\alpha$ and $\mathrm{H}_{2} \mathrm{O}_{2}$ treated group without GSH.
Table $V$. Effect of Oxypurinol on TNF $\alpha$-induced Changes of GSH and GSSG in Endothelial Cells

\begin{tabular}{|c|c|c|c|}
\hline & GSH & GSSG & $\begin{array}{c}\text { GSSG/GSH } \\
\text { ratio }\end{array}$ \\
\hline \multicolumn{4}{|c|}{ nmol/10 cells } \\
\hline Control & $5.96 \pm 0.13$ & $0.15 \pm 0.03$ & $0.025 \pm 0.006$ \\
\hline TNF $\alpha$ & $4.80 \pm 0.31^{*}$ & $0.26 \pm 0.02^{*}$ & $0.054 \pm 0.006^{*}$ \\
\hline Oxypurinol & $6.21 \pm 0.27$ & $0.25 \pm 0.05^{*}$ & $0.040 \pm 0.010^{*}$ \\
\hline \multicolumn{4}{|l|}{ Oxypurinol } \\
\hline$+\mathrm{TNF} \alpha$ & $6.18 \pm 0.26$ & $0.24 \pm 0.04^{*}$ & $0.039 \pm 0.008^{*}$ \\
\hline
\end{tabular}

Endothelial cells were incubated with or without TNF $\alpha(100 \mathrm{U} / \mathrm{ml})$ for $6 \mathrm{~h} .0 .5 \mathrm{mM}$ oxypurinol was added $30 \mathrm{~min}$ before the 6-h incubation. Values are means \pm SE; $n=6$.

* $P<0.05$ compared with control.

$100 \mathrm{U} / \mathrm{ml}$ TNF $\alpha$ prevented the synergistic effect of the TNF $\alpha$ and $\mathrm{H}_{2} \mathrm{O}_{2}$ regimen in increasing transendothelial ${ }^{125} \mathrm{I}$-albumin permeability (Fig. 7). Treatment with oxypurinol alone had no effect on baseline permeability values. Oxypurinol added at the end of the TNF $\alpha$ treatment period had no protective effect, excluding the possibility that residual oxypurinol directly interfered with the $\mathrm{H}_{2} \mathrm{O}_{2}$ effect.

Morphological changes. Control cells showed characteristic peripheral bands and close cell-cell contact (Fig. $8 \mathrm{~A}$ ). Neither TNF $\alpha(100 \mathrm{U} / \mathrm{ml}, 6 \mathrm{~h})$ nor $\mathrm{H}_{2} \mathrm{O}_{2}(10 \mu \mathrm{M}, 1 \mathrm{~h})$ treatments caused significant change in this pattern. TNF $\alpha$ treatment and subsequent $\mathrm{H}_{2} \mathrm{O}_{2}$ challenge resulted in the development of randomly oriented stress fibers, disappearance of peripheral bands, cell retraction, and intercellular gaps (Fig. $8 \mathrm{~B}$ ). Addition of oxypurinol $30 \mathrm{~min}$ before TNF $\alpha$ treatment prevented the changes caused by the combination of TNF $\alpha$ and $\mathrm{H}_{2} \mathrm{O}_{2}$ (Fig. $8 C$ ).

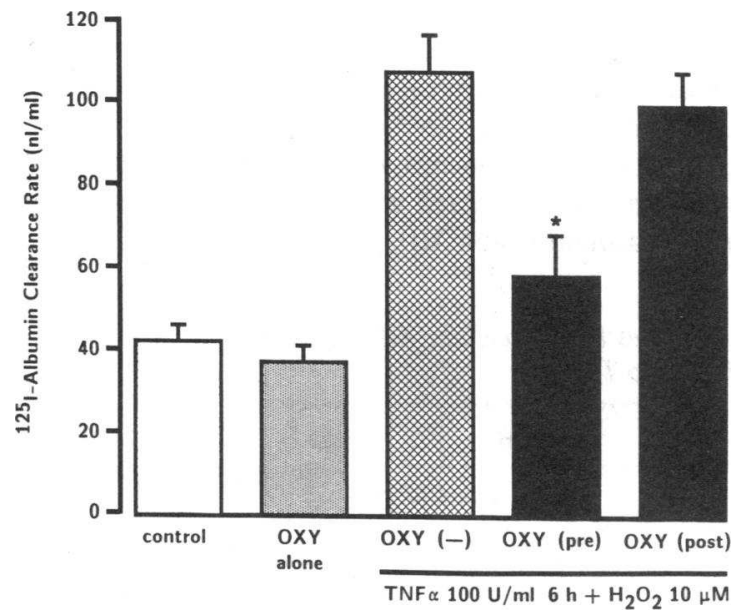

Figure 7. Effect of oxypurinol on increased endothelial permeability induced by a combination of TNF $\alpha$ and subsequent $\mathrm{H}_{2} \mathrm{O}_{2}$. Oxypurinol was added to the medium $30 \mathrm{~min}$ before (pre) or at the end (post) of TNF $\alpha$ treatment $(100 \mathrm{U} / \mathrm{ml}$ for $6 \mathrm{~h})$. The transendothelial ${ }^{125} \mathrm{I}$-albumin clearance rates were measured after addition of $10 \mu \mathrm{M} \mathrm{H}_{2} \mathrm{O}_{2}$. Values are means \pm SE; $n=8$ in each group. ${ }^{*} P<0.05$ significantly decreased when compared with the TNF $\alpha$ - and $\mathrm{H}_{2} \mathrm{O}_{2}$-treated groups without oxypurinol. 

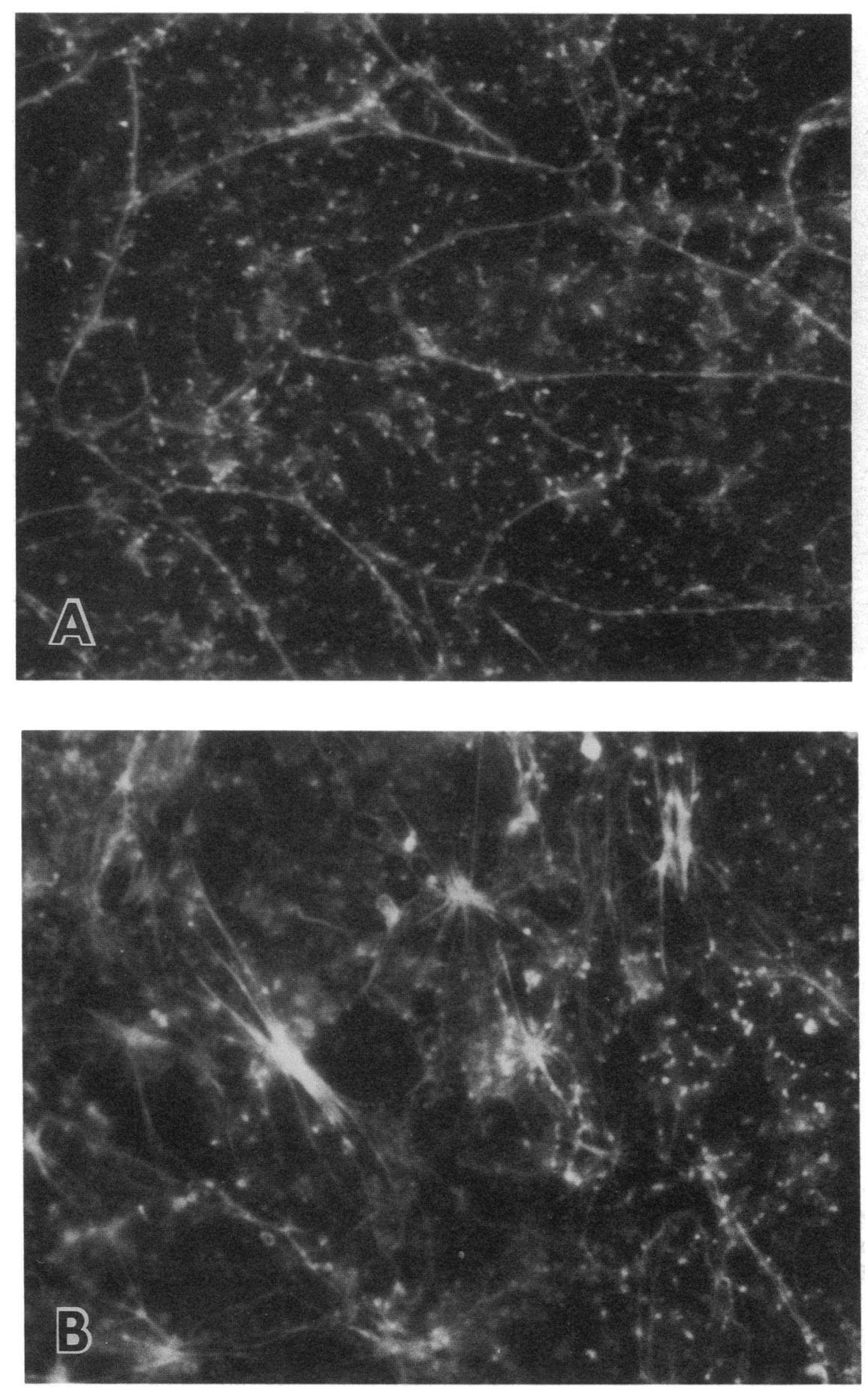

Figure 8. Morphological changes in endothelial cells. Monolayers were stained for actin microfilaments using rhodamine phalloidin (see Methods). ( $A$ ) Control monolayer, $(B)$ monolayers treated with TNF $\alpha(100 \mathrm{U} / \mathrm{ml}, 6 \mathrm{~h})$ and subsequent $\mathrm{H}_{2} \mathrm{O}_{2}(10 \mu \mathrm{M}, 1 \mathrm{~h})$, and $(C)$ as in $(B)$ except with 30 -min pretreatment with 0.5 mM oxypurinol $(\times 500)$.

\section{Discussion}

TNF $\alpha$ is an important mediator of endotoxic shock and the associated increase in vascular endothelial permeability and tissue edema as observed in the adult respiratory distress syndrome $(1,2)$. Several studies have suggested a critical role for TNF $\alpha$ in the pathogenesis of lung vascular injury in adult respiratory distress syndrome $(3,4,35,36)$. In previous studies, concentrations of TNF $\alpha$ ranging from 0.5 to $22 \mathrm{ng} / \mathrm{ml}$ were shown to increase endothelial permeability and produce actin cytoskeletal redistribution (7) in the absence of cytolysis $(5,6)$.
However, it is doubtful that these concentrations of TNF $\alpha$ alone can explain the high permeability pulmonary edema associated with endotoxemia. Serum TNF $\alpha$ concentrations in septic patients are relatively low (median concentration in nonsurvivors of $0.33 \mathrm{ng} / \mathrm{ml}$ ) and almost never exceed $4 \mathrm{ng} / \mathrm{ml}$ (corresponding to $100 \mathrm{U} / \mathrm{ml}$ of TNF $\alpha$ used in this study) (37, 38). We showed in this study that endothelial permeability did not increase in BPMVEC in response to $4 \mathrm{ng} / \mathrm{ml}(100 \mathrm{U} / \mathrm{ml})$ TNF $\alpha$. However, even a low TNF $\alpha$ concentration $(100 \mathrm{U} / \mathrm{ml})$, which had no direct permeability-increasing effect, was capable of "priming" endothelial cells and rendering them susceptible 


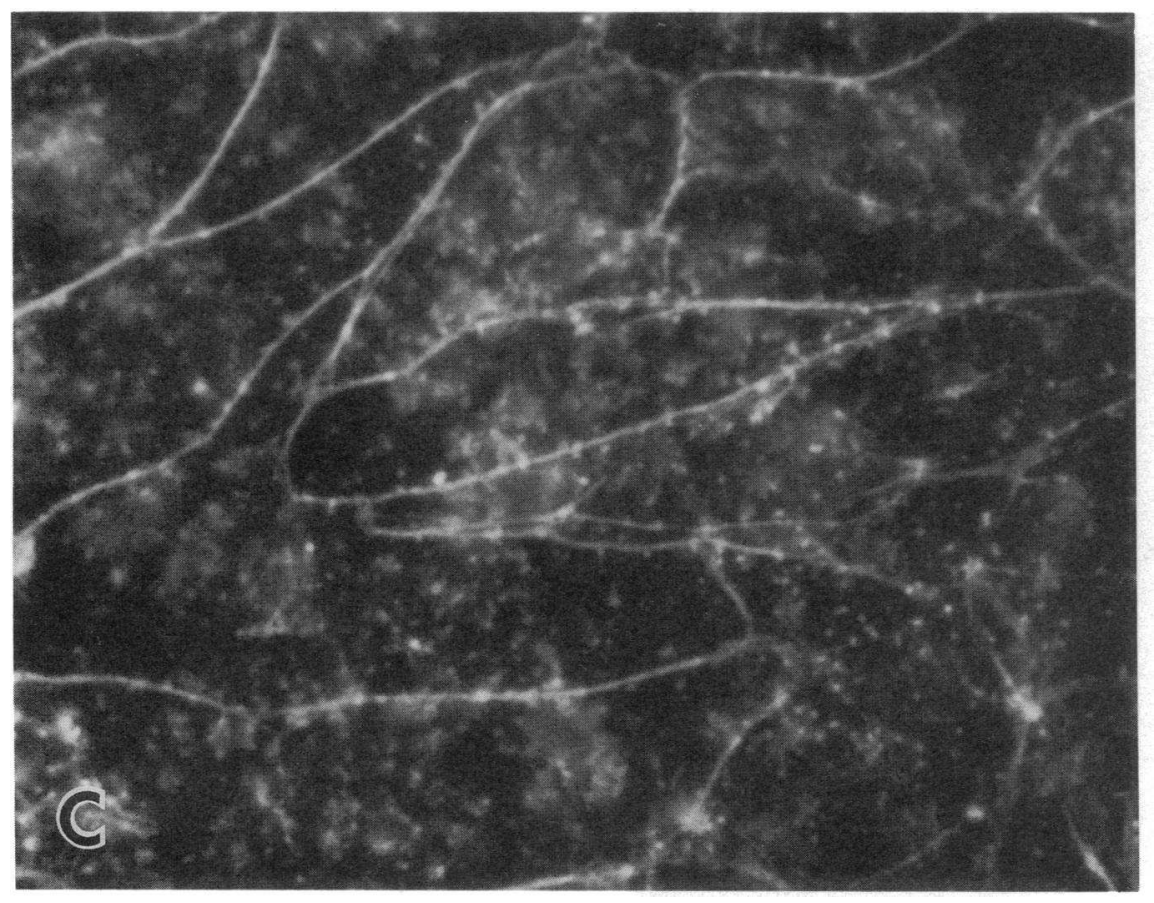

Figure 8 (Continued)

to injury by $\mathrm{H}_{2} \mathrm{O}_{2}$, an oxidant produced by activated PMN (39). Therefore, $\mathrm{H}_{2} \mathrm{O}_{2}$ resulted in an increase in endothelial permeability in TNF $\alpha$ "primed" cells even at an $\mathrm{H}_{2} \mathrm{O}_{2}$ concentration of $10 \mu \mathrm{M}$ that in control endothelial cells had no effect on permeability.

The permeability-increasing effect of subthreshold concentrations of TNF $\alpha$ combined with $\mathrm{H}_{2} \mathrm{O}_{2}$ was associated with changes in the shape of endothelial cells and redistribution of cytoskeletal actin filaments, but was not the result of cytolysis. The observed effects were also not due to contamination of the TNF $\alpha$ preparation, since heat-inactivation of the cytokine had no effect and neutralizing TNF $\alpha$ with an antibody prevented the TNF $\alpha$-mediated augmentation of the permeability increase.

In light of observations that sensitivity of cultured tumor cells to TNF $\alpha$ can be regulated by the capacity of these cells to scavenge free radicals (25), we examined a possible basis of the TNF $\alpha$-mediated effect on permeability by determining alterations in intracellular antioxidants of TNF $\alpha$-exposed BPMVEC to $\mathrm{H}_{2} \mathrm{O}_{2}$. There is some precedence for invoking a role of TNF $\alpha$ in modulating intracellular antioxidants. Intravenous administration of TNF $\alpha$ in rats increased plasma GSSG concentration (40), an index of oxidation of the antioxidant GSH (41). TNF $\alpha$ has also been shown to decrease intracellular thiols, with the most abundant being GSH (42). Since the GSH redox cycle as well as intracellular catalase are the primary antioxidant defense mechanisms against $\mathrm{H}_{2} \mathrm{O}_{2}(26)$, we determined whether TNF $\alpha$-mediated alterations in intracellular GSH and catalase contributed to the increased susceptibility of TNF $\alpha$-exposed endothelial cells to $\mathrm{H}_{2} \mathrm{O}_{2}$. The results indicated that the GSH content was reduced in a concentration-dependent manner after TNF $\alpha$ challenges. TNF $\alpha$ appeared to be responsible for GSH oxidation since the decrease in GSH was associated with a concomitant increase in GSSG content. A likely mechanism of reduction in GSH content may be generation of oxidants during TNF $\alpha$ exposure and the conversion of GSH to GSSG (43). GSSG formed by oxidative stress is subsequently reduced by glutathione reductase and reconverted to GSH; however, intracellular GSSG may accumulate when the rate of GSSG formation exceeds that of its reduction or when the glutathione reductase system is impaired (43). In such a case, GSSG can be extruded into the extracellular space or may form mixed disulfides with intracellular or extracellular proteins resulting in a net loss of GSH (44). In this study, only a small increase in GSSG in the medium was detected in conjunction with intracellular accumulation of GSSG after treatment with TNF $\alpha$; therefore, a major part of loss of GSH induced by TNF $\alpha$ may be the result of formation of mixed disulfides.

The decrease in intracellular GSH content was seen in parallel with the increase in permeability; that is, GSH content decreased slightly after the 3-h TNF $\alpha$ treatment and this was associated with increased susceptibility to $\mathrm{H}_{2} \mathrm{O}_{2}$, but the greater decrease in GSH occurring within $6 \mathrm{~h}$ after TNF $\alpha$ treatment augmented the sensitivity to $\mathrm{H}_{2} \mathrm{O}_{2}$. Tsan et al. (26) have reported that depletion of cellular GSH by the GSH synthesis inhibitor, buthionine sulphoxamine, increased the susceptibility of endothelial cells to lysis by $\mathrm{H}_{2} \mathrm{O}_{2}$. The role of decreased cellular GSH observed in the present study in enhancing endothelial sensitivity to $\mathrm{H}_{2} \mathrm{O}_{2}$ is consistent with this observation.

In contrast to the TNF $\alpha$-induced decrease in intracellular GSH content, even high concentrations of TNF $\alpha$ had no signifcant effect on the endothelial catalase activity. Shiki et al. (45) also showed that high concentration of endotoxin did not alter $\mathrm{Cu} / \mathrm{Zn}$ SOD and catalase contents in cultured bovine endothelial cells, although Mn SOD content was significantly increased. Similarly, Shaffer et al. (46) have shown that a high concentration of TNF $\alpha$ did not affect either catalase or $\mathrm{CuZn}$ 
SOD mRNA signals. Therefore, endothelial cell catalase activity appears to be resistant to TNF $\alpha$, and it is therefore unlikely that it is an important determinant of the increased susceptibility to $\mathrm{H}_{2} \mathrm{O}_{2}$ observed in TNF $\alpha$-treated endothelial cells.

Since the decrease in cellular GSH content may be a determinant of the observed increase in sensitivity of endothelial cells to $\mathrm{H}_{2} \mathrm{O}_{2}$, we tested whether supplementation of $\mathrm{GSH}$ might prevent the "priming" effect of TNF $\alpha$ on endothelial cells. Exogenous GSH increased the intracellular GSH concentration by $180 \%$ as has been demonstrated previously using endothelial cells (30). This increase in GSH significantly reduced the $\mathrm{H}_{2} \mathrm{O}_{2}$-mediated increase in endothelial permeability in TNF $\alpha$-treated endothelial cells.

The question of why TNF $\alpha$ caused the reduction in the endothelial GSH content is unresolved. Generation of oxygen free radicals by endothelial cells in response to TNF $\alpha$ (11) may cause oxidation of GSH, and thus may contribute to the decrease in GSH content. Possible sources of the oxygen free radical induced by TNF $\alpha$ include activation of $(a) \mathrm{XO}(12)$ and (b) arachidonic acid metabolism (11). The source of oxidants may depend on species and organs from which endothelial cells were derived. Schuger et al. (36) showed that TNF $\alpha$-induced cytotoxicity in human umbilical vein endothelial cells was prevented with cyclooxygenase inhibitors, but not the XO inhibitor, allopurinol. In contrast, endotoxin-induced injury of bovine pulmonary endothelial cells was prevented with allopurinol (47). In this study oxypurinol (used in a concentration that inhibited XO activity in BPMVEC) prevented both the decrease in cellular GSH content and the increase in permeability that occurred in the combination TNF $\alpha$ and $\mathrm{H}_{2} \mathrm{O}_{2}$ regimen. This finding suggests that $\mathrm{XO}$ activation may be the source of oxygen free radical after TNF $\alpha$ challenge of BPMVEC and that this is responsible for oxidation of GSH.

In summary, we have shown that TNF $\alpha$ pretreatment of endothelial cells for 3-6 h significantly augmented the increase in endothelial permeability in response to $\mathrm{H}_{2} \mathrm{O}_{2}$. This effect was due to the TNF $\alpha$-mediated decrease in intracellular GSH content since supplementation of GSH significantly inhibited the TNF $\alpha$ "priming" effect on endothelial permeability. Pretreatment of endothelial cells with the XO inhibitor, oxypurinol, also prevented the TNF $\alpha$-induced sensitization of endothelial cells after $\mathrm{H}_{2} \mathrm{O}_{2}$ exposure. We conclude that TNF $\alpha$ induced decrease in intracellular GSH mediates the increased susceptibility of endothelial cells to $\mathrm{H}_{2} \mathrm{O}_{2}$. This effect of TNF $\alpha$ on endothelial cells may play a critical role in the high-permeability pulmonary edema associated with endotoxic shock.

\section{Acknowledgments}

We thank Ms. Linda Lai for expert technical assistance and Ms. Lynn McCarthy for the excellent secretarial assistance.

This study was supported by grants HL-27106, HL-32418, and HL45638 from the National Institutes of Health.

Note added in proof. A study appearing since the acceptance of this manuscript (Marcho, Z., J. E. White, P. G. Higgins, and M.-F. Tsan. 1991. Am. J. Respir. Cell Mol. Biol. 5:556-562), has shown that TNF- $\alpha$ enhances endothelial cytotoxicity to hyperoxia $\left(95 \% \mathrm{O}_{2}\right)$, which was the result in part of a reduction in intracellular GSH. This finding is consistent with the present observations concerning the role of TNF- $\alpha$-induced decrease in GSH in augmenting the increase in vascular endothelial permeability mediated by $\mathrm{H}_{2} \mathrm{O}_{2}$.

\section{References}

1. Tracey, K. J., B. Beutler, S. F. Lowry, J. Merryweather, S. Wolpe, I. W. Milsark, R. J. Hariri, T. J. Fahey III, A. Zentella, J. D. Albert, G. T. Shires, and A. Cerami. 1986. Shock and tissue injury induced by recombinant human cachectin. Science (Wash. DC). 234:470-474.

2. Tracey, K. J., Y. Fong, D. G. Hesse, K. R. Manogue, A. T. Lee, G. C. Kuo, S. F. Lowry, and A. Cerami. 1987. Anti-cachectin/TNF monoclonal antibodies prevent septic shock during lethal bacteraemia. Nature (Lond.). 330:662-664.

3. Horvath, C. J., T. J. Ferro, G. Jesmok, and A. B. Malik. 1988. Recombinant tumor necrosis factor increases pulmonary vascular permeability independent of neutrophils. Proc. Natl. Acad. Sci. USA. 85:9219-9223.

4. Stephens, K. E., A. Ishizaka, J. W. Larrick, and T. A. Raffin. 1988. Tumor necrosis factor causes increased pulmonary permeability and edema: comparison to septic acute lung injury. Am. Rev. Respir. Dis. 137:1364-1370.

5. Royall, J. A., R. L. Berkew, J. S. Beckman, M. K. Cunningham, S. Matalon, and B. A. Freeman. 1989. Tumor necrosis factor and interleukin $1 \alpha$ increase vascular endothelial permeability. Am. J. Physiol. 257:L399-L410.

6. Goldblum, S. E., and W. L. Sun. 1990. Tumor necrosis factor- $\alpha$ augments pulmonary arterial transendothelial albumin flux in vitro. Am. J. Physiol. 258:L57-L67.

7. Brett, J., H. Gerlach, P. Nawroth, S. Steinberg, G. Godman, and D. Stern 1989. Tumor necrosis factor/cachectin increases permeability of endothelial cell monolayers by a mechanism involving regulatory $\mathrm{G}$ proteins. J. Exp. Med. 169:1977-1991.

8. Bussolino, F., G. Camussi, and C. Baglioni. 1988. Synthesis and release of platelet-activating factor by human vascular endothelial cells treated with tumor necrosis factor or interleukin 1 alpha. J. Biol. Chem. 263:11856-11861.

9. Nawroth, P. P., I. Bank, D. Handley, J. Cassimeris, L. Chess, and D. Stern. 1986. Tumor necrosis factor/cachectin interacts with endothelial cell receptors to induce release of interleukin 1. J. Exp. Med. 163:1363-1375.

10. Broudy, V. C., K. Kaushansky, G. M. Segal, J. M. Harlan, and J. W. Adamson. 1986. Tumor necrosis factor type alpha stimulates human endothelial cells to produce granulocyte/macrophage colony-stimulating factor. Proc. Natl. Acad. Sci. USA. 83:7467-7471.

11. Larrick, J. W., and S. C. Wright. 1990. Cytotoxic mechanism of tumor necrosis factor- $\alpha$. FASEB (Fed. Am. Soc. Exp. Biol.) J. 4:3215-3223.

12. Friedl, H. P., G. O. Till, U. S. Ryan, and P. A. Ward. 1989. Mediator-induced activation of xanthine oxidase in endothelial cells. FASEB (Fed. Am. Soc. Exp. Biol.) J. 3:2512-2518.

13. Stephens, K. E., A. Ishizaka, Z. H. Wu, J. W. Larrick, and T. A. Raffin. 1988. Granulocyte depletion prevents tumor necrosis factor-mediated acute lung injury in guinea pigs. Am. Rev. Respir. Dis. 138:1300-1307.

14. Heflin, A. C., and K. L. Brigham. 1981. Prevention by granulocyte depletion of increased vascular permeability of sheep lung following endotoxemia. $J$. Clin. Invest. 68:1253-1260.

15. Shasby, D. M., S. S. Shasby, and M. J. Peach. 1983. Granulocytes and phorbol myristate increase permeability to albumin of cultured endothelial monolayers and isolated perfused lungs. Am. Rev. Respir. Dis. 127:72-76.

16. Kaslovsky, R. A., M. J. Horgan, H. Lum, B. K. McCandless, N. Gilboa, S. D. Wright, and A. B. Malik. 1990. Pulmonary edema induced by phagocytosing neutrophils. Protective effect of monoclonal antibody against phagocyte CD 18 integrin. Circ. Res. 67:795-802.

17. Larrick, J. W., D. Graham, K. Toy, L. S. Lin, G. Senyk, and B. M. Fendly. 1987. Recombinant tumor necrosis factor causes activation of human granulocytes. Blood. 69:640-644.

18. Roubin, R., P. P. Elsas, W. Fiers, and A. J. Dessein. 1987. Recombinant human tumour necrosis factor (rTNF) enhances leukotriene biosynthesis in neutrophils and eosinophils stimulated with the $\mathrm{Ca}^{2+}$ ionophore A23187. Clin. Exp. Immunol. 70:484-490.

19. Johnson, A., P. Phillips, D. Hocking, M. Tsan, and T. Ferro. 1989. Protein kinase inhibitor prevents pulmonary edema in response to $\mathrm{H}_{2} \mathrm{O}_{2} . A m$. J. Physiol. 256:H1012-H1022.

20. Pober, J. S., M. A. Gimbrone, Jr., L. A. Lapierre, D. L. Mendrick, W. Fiers, R. Rothlein, and T. A. Springer. 1986. Overlapping patterns of activation of human endothelial cells by interleukin 1, tumor necrosis factor, and immune interferon. J. Immunol. 137:1893-1896.

21. Bevilacqua, M. P., J. S. Pober, D. L. Mendrick, R. S. Cotran, and M. A. Gimbrone, Jr. 1987. Identification of an inducible endothelial-leukocyte adhesion molecule. Proc. Natl. Acad. Sci. USA. 84:9238-9242.

22. Nathan, C. F. 1987. Neutrophil activation on biological surfaces. Massive secretion of hydrogen peroxide in response to products of macrophages and lymphocytes. J. Clin. Invest. 80:1550-1560.

23. Varani, J., M. J. Bendelow, D. E. Sealey, S. L. Kunkel, D. E. Gannon, 
U. S. Ryan, and P. A. Ward. 1988. Tumor necrosis factor enhances susceptibility of vascular endothelial cells to neutrophil-mediated killing. Lab. Invest. 59:292295.

24. Slungaard, A., G. M. Vercellotti, G. Walker, R. D. Nelson, and H. S. Jacob. 1990. Tumor necrosis factor alpha/cachectin stimulates eosinophil oxidant production and toxicity towards human endothelium. J. Exp. Med. 171:2025-2041.

25. Zimmerman, R. J., A. Chan, and S. A. Leadon. 1989. Oxidative damage in murine tumor cells treated in vitro by recombinant human tumor necrosis factor. Cancer Res. 49:1644-1648.

26. Tsan, M. F., E. H. Danis, P. J. Del Vecchio, and C. L. Rosano. 1985. Enhancement of intracellular glutathione protects endothelial cells against oxidant damage. Biochem. Biophys. Res. Commun. 127:270-276.

26a.Gibbs, L.S., L. Lai, and A. B. Malik. 1990. Tumor necrosis factor enhances the neutrophil-dependent increase in endothelial permeability. J. Cell Physiol. 145:496-500.

27. Del Vecchio, P. J., J. W. Ryan, A. Chang, and U. S. Ryan. 1980. Capillaries of the adrenal cortex possess aminopeptidase $A$ and angiotensin-converting enzyme activities. Biochem. J. 186:605-608.

28. Garcia, J. G., A. Siflinger-Birnboim, R. Bizios, P. J. Del Vecchio, J. G. Fenton II, and A. B. Malik. 1986. Thrombin-induced increase in albumin permeability across the endothelium. J. Cell. Physiol. 128:96-104.

29. Cooper, J. A., P. J. Del Vecchio, F. L. Minnear, K. E. Burhop, W. M. Selig, J. G. Garcia, and A. B. Malik. 1987. Measurement of albumin permeability across endothelial monolayers in vitro. J. Appl. Physiol. 62:1076-1083.

30. Tsan, M. F., J. E. White, and C. L. Rosano. 1989. Modulation of endothelial GSH concentrations: effect of exogenous GSH and GSH monoethyl ester. $J$. Appl. Physiol. 66:1029-1034.

31. Terada, L. S., C. J. Beehler, A. Banerjee, J. M. Brown, M. A. Grosso, A. H. Harken, J. M. McCord, and J. E. Repine. 1988. Hyperoxia and self- or neutrophil-generated $\mathrm{O}_{2}$ metabolites inactivate xanthine oxidase. J. Appl. Physiol. 65:2349-2353.

32. Griffith, O. W. 1980. Determination of glutathione and glutathione disulfide using glutathione reductase and 2-vinylpyridine. Anal. Biochem. 106:207212.

33. Beers, R. F., Jr., and I. W. Sizer. 1952. A spectrophotometric method for measuring the breakdown of hydrogen peroxide by catalase. J. Biol. Chem. 195:133-140.

34. Phillips, P. A., and M. F. Tsan. 1988. Direct staining and visualization of endothelial monolayers cultured on synthetic polycarbonate filters. J. Histochem. Cytochem. 36:551-554.

35. Clark, M. A., M. J. Chen, S. T. Crooke, and J. S. Bomalaski. 1988. Tumor necrosis factor (cachectin) induces phospholipase $A_{2}$ activity and synthesis of a phospholipase $A_{2}$-activating protein in endothelial cells. Biochem. J. 250:125132.

36. Schuger, L., J. Varani, R. M. Marks, S. L. Kunkel, K. J. Johnson, and P. A. Ward. 1989. Cytotoxicity of tumor necrosis factor-alpha for human umbilical vein endothelial cells. Lab. Invest. 61:62-68.

37. Calandra, T., J. D. Baumgartner, G. E. Grau, M. M. Wu, P. H. Lambert, J. Schellekens, J. Verhoef, and M. P. Glauser. 1990. Prognostic values of tumor necrosis factor/cachectin, interleukin-1, interferon-alpha, and interferon-gamma in the serum of patients with septic shock: Swiss-Dutch J5 immunoglobulin study group. J. Infect. Dis. 161:982-987.

38. Roten, R., M. Markert, F. Feihl, M. Schaller, M. Tagan, and C. Perret. 1991. Plasma levels of tumor necrosis factor in the adult respiratory distress syndrome. Am. Rev. Respir. Dis. 143:590-592.

39. Weiss, S. J., J. Young, A. F. RoBuglio, A. Slivka, and N. F. Nimeh. 1981. Role of hydrogen peroxide in neutrophil-mediated destruction of cultured endothelial cells. J. Clin. Invest. 68:714-720.

40. Chang, S. W., N. Ohara, G. Kuo, and N. F. Voelkel. 1989. Tumor necrosis factor-induced lung injury is not mediated by platelet-activating factor. Am. J. Physiol. 257:232-239.

41. Adam, J. D., Jr., B. H. Lauterburg, and J. R. Mitchell. 1983. Plasma glutathione and glutathione disulfide in the rat: regulation and response to oxidative stress. J. Pharmacol. Exp. Ther. 227:749-754.

42. Staal, F. J. T., M. Roederer, L. A. Herzenberg, and L. A. Herzenberg. 1990. Intracellular thiols regulates activation of nuclear factor $\kappa \mathrm{B}$ and transcription of hum: immunodeficiency virus. Proc. Natl. Acad. Sci. USA. 87:99439947.

43. Bellomo, G., F. Mirabelli, D. DiMonte, P. Richelmi, H. Thor, C. Orrenius, and S. Oriunius. 1987. Formation and reduction of glutathione-protein mixed disulfides during oxidative stress. Biochem. Pharmacol. 36:1313-1320.

44. Deneke, S. M., and B. L. Fanburg. 1989. Regulation of cellular glutathione. Am. J. Physiol. 257:L163-173.

45. Shiki, Y., B. O. Meyrick, K. L. Brigham, and I. M. Burr. 1987. Endotoxin increases superoxide dismutase in cultured bovine pulmonary endothelial cells. Am. J. Physiol. 252:C436-440.

46. Shaffer, J. B., C. P. Treanor, and P. J. Del Vecchio. 1990. Expression of bovine and mouse endothelial cell antioxidant enzymes following TNF- $\alpha$ exposure. Free Rad. Biol. Med. 8:497-502.

47. Brigham, K. L., B. Meyrick, L. C. Berry, Jr., and J. E. Repine. 1987. Antioxidants protect cultured bovine lung endothelial cells from injury by endotoxin. J. Appl. Physiol. 63:840-850. 